\title{
Correction to: Methodological guidelines to estimate population-based health indicators using linked data and/or machine learning techniques
}

Romana Haneef ${ }^{1 *}$, Mariken Tijhuis ${ }^{2}$, Rodolphe Thiébaut ${ }^{3,4,5}$, Ondřej Májek ${ }^{6,7}$, Ivan Pristaš ${ }^{8}$, Hanna Tolonen ${ }^{9}$ and Anne Gallay ${ }^{1}$

Correction to: Arch Public Health 80, 9 (2022)

https://doi.org/10.1186/s13690-021-00770-6

Following publication of the original article [1], the authors reported that the sixth author's family name was incorrectly spelled as "Tolenan".

The correct spelling of the family name "Tolonen" has been provided in this Correction.

The original article [1] has been updated.

\section{Reference}

1. Haneef $R$, Tijhuis $M$, Thiébaut $R$, et al. Methodological guidelines to estimate population-based health indicators using linked data and/or machine learning techniques. Arch Public Health. 2022;80:9. https://doi org/10.1186/s13690-021-00770-6.

\begin{abstract}
Author details
${ }^{1}$ Department of Non-Communicable Diseases and Injuries, Santé Publique France, Saint-Maurice, France. ${ }^{2}$ National Institute for Public Health and the Environment (RIVM), Bilthoven, The Netherlands. ${ }^{3}$ Bordeaux University, Bordeaux School of Public Health, Bordeaux, France. ${ }^{4}$ INSERM / INRIA SISTM team, Bordeaux Population Health, Bordeaux, France. ${ }^{5}$ Medical Information Department, Bordeaux University Hospital, Bordeaux, France. ${ }^{6}$ Institute of Health Information and Statistics of the Czech Republic, Prague, Czech Republic. ${ }^{7}$ Institute of Biostatistics and Analyses, Faculty of Medicine, Masaryk University, Brno, Czech Republic. ${ }^{8}$ National Institute of Public Health, Division of Health Informatics and Biostatistics, Zagreb, Croatia. ${ }^{9}$ Finnish Institute for Health and Welfare (THL), Helsinki, Finland.
\end{abstract}

Published online: 23 February 2022 original author(s) and the source, provide a link to the Creative Commons licence, and indicate if changes were made. The images or other third party material in this article are included in the article's Creative Commons licence, unless indicated otherwise in a credit line to the material. If material is not included in the article's Creative Commons licence and your intended use is not permitted by statutory regulation or exceeds the permitted use, you will need to obtain permission directly from the copyright holder. To view a copy of this licence, visit http://creativecommons.org/licenses/by/4.0/. The Creative Commons Public Domain Dedication waiver (http://creativeco mmons.org/publicdomain/zero/1.0/) applies to the data made available in this article, unless otherwise stated in a credit line to the data. 